\title{
Uji Validitas dan Reliabilitas Alat Ukur SG Posture Evaluation
}

\author{
Sugiono $^{1 *}$, Noerdjanah ${ }^{2}$, Afrianti Wahyu ${ }^{3}$ \\ 1,2,3 Poltekkes Kemenkes Surakarta Jurusan Fisioterapi \\ Email: sugifisio@gmail.com
}

\begin{abstract}
Background: The SG Posture Evaluation measuring tool is designed and made to measure changes in posture in adults and children. the level of validity and reliability of the SG Posture Evaluation measuring instrument is needed. The purpose of this study is to determine the level of validity and reliability of the SG Posture Evaluation measuring instrument. The benefits of this study as a scientific reference related to the validity and reliability of the SG Posture Evaluation can be used in the community. Methods: The research method used through quantitative research. The sampling technique is purposive sampling, the number of samples is 84, there are 2 categories and there are 10 claims / items, ranking 5 parallel to the spine and 5 items from the side of the neck (neck, shoulders, thorax, lumbar and pelvis), data discussed with Pearson and apronha cronbach. Results: Valid results, Rating from back: Item number 2 (Shoulder value 323), item number 5 (Pelvic 260) and side-side values obtained: Item number 1 (Neck 747), Item number 2 (Shoulder value 276), Item number 3 (Thoraks value 301), Item number 4 (Lumbar value 489) Item number 5 (Pelvic 334). While invalid results, Value from back: Item number 1 (Neck value 170), Item number 3 (Thorax value 128), Item number (4) (Lumbar value 0); goods. The level of reliability with an alpha cronback value of 612 values greater than 0.6. Conclusion: There is validity and reliability of the SG Posture Evaluation measuring instrument.
\end{abstract}

Keywords: validity test, reliability test, measuring instruments, SG posture evaluation

\section{PENDAHULUAN}

Validitas berasal dari kata validity yang berarti keabsahan atau kebenaran. Validitas mempunyai arti sejauh mana ketepatan dan kecermatan alat ukur mampu melakukan fungsi ukurnya. Menurut Sugiyono (2005) Validitas adalah suatu indeks yang menunjukkan alat ukur itu benar-benar mengukur apa yang hendak diukur. Selain validitas, alat ukur yang baik juga harus reliabel. Reliabilitas diterjemahkan dari kata reliability yang berarti hal yang dapat dipercaya (tahan uji).

Reliabilitas adalah indeks yang menunjukkan sejuh mana suatu alat pengukur dapat dipercaya atau diandalkan. Hal ini menunjukkan sejauh mana hasil pengukuran itu tetap konsisten bila dilakukan dua kali atau lebih terhadap gejala yang sama, dengan menggunakan alat ukur yang sama (Notoatmodjo 2005).
Alat ukur dikatakan reliabel jika menghasilkan hasil yang sama meskipun dilakukan pengukuran berkali-kali (Kendra 2012). Sebuah tes dikatakan mempunyai reliabilitas yang tinggi jika tes tersebut memberikan data dengan hasil yang ajeg (tetap) walaupun diberikan pada waktu yang berbeda kepada responden yang sama. Oleh karena itu, alat ukur yang baik adalah alat ukur yang valid dan reliabel.

Hubungan antara validitas dengan reliabilitas dapat digambarkan sebagaimana tembakan yang selalu tepat mengenai sasaran yang diinginkan. Sebuah alat ukur yang valid selalu reliabel. Akan tetapi alat ukur yang reliabel belum tentu valid. Validitas dan reliabilitas setiap alat ukur sangat penting dalam mementukan akurat atau tidak alat tersebut, begitu juga alat Alat ukur SG 
Posture Evaluation yang akan diuji tingkat validitas (keabsahan atau kebenaran) dan validitas (ketepatan alat ukur).

Alat ukur SG Posture Evaluation didesain dan dibuat untuk mengukur perubahan postur baik pada orang dewasa dan anak-anak. Tanda umum perubahan postur antara lain tulang bahu yang berbeda, tulang belikat yang menonjol, lengkungan tulang belakang yang nyata, panggul yang miring, perbedaan antara ruang lengan dan tubuh. Lengkungan skoliosis idiopatik kemungkinan akan berkembang seiring pertumbuhan. Biasanya, semakin muda waktu kejadian pada anak yang struktur lengkungannya sedang berkembang maka semakin serius prognosisnya (Sari et al., 2013). Perubahan postur sangat erat kaitannya dengan kesehatan seseorang.

Kesehatan adalah keadaan sehat baik secara fisik, mental dan spiritual maupun sosial yang memungkinkan setiap orang untuk hidup produktif secara sosial dan ekonomi (UU No 36 tahun 2009). Keadaan sehat secara fisik salah satunya tidak adanya perubahan postur pada seseorang. Perubahan postur apabila diukur dan diagnosa sedini mungkin setidaknya dapat memberikan informasi kepada penderita dan keluarga bahwa terjadi pembengkokan tulang belakang, sehingga dapat diberikan penanganan lebih lanjut untuk mencegah terjadinya pembengkokan tulang belakang yang lebih besar derajatnya sehingga tidak mengalami deformitas yang lebih parah.

Alat ukur postur SG Posture Evaluation apabila di uji validitas dan uji reliabilitas, menggambarkan tingkat validitas dan uji reliabilitas dan apabila digunakan untuk pengukuran hasilnnya akan lebih baik. Penelitian yang berkaitan dengan uji validitas dan uji reliabilitas secara umum pernah dilakukan sebelumnya oleh Bhisma (2011), Zulkifli (2009), dan Kogovseka dkk (2002). Secara umum pendekatan dalam meneliti validitas suatu alat ukur terdiri dari 3, yaitu 1) validitas isi, 2) validitas konstruk, dan 3) validitas kriteria (Suryabrata, 2005). Validitas isi adalah validitass yang fokus kepada elemen-elemen apa yang ada dalam ukur (Coaley, 2010), sehingga analisis rasional adalah proses utama yang dilakukan dalam analisis validitas isi (Azwar, 2005). Validitas kriteria adalah mengaitkan alat ukur dengan alat ukur lain sebagai kriteria, apakah alat ukur ukur itu bisa dijelaskan hasil korelasinya dengan dengan kriterianya berdasarkan teori yang ada (Devellis, 2003).

Validitas konstruk adalah sebuah gambaran yang menunjukkan sejauhmana alat ukur itu menunjukkan hasil yang sesuai dengan teori (Azwar, 2005). Proses pengujian validitas konstruk adalah menghubungkan alat ukur itu dengan alat ukur lain yang memiliki kesamaan konsep atau dengan alat ukur-alat ukur lain yang secara teoritis berkaitan dengan SG Posture Evaluation.

Tujuan penelitian ini untuk mengetahui uji validitas dan reliabilitas SG Posture Evaluation

\section{METODE PENELITIAN}

Metode penelitian yang digunakan dalam penelitian ini melalui pendekatan kuantitatif. Menurut Sugiyono (2016) metode penelitian kuantitatif dapat diartikan sebagai metode penelitian yang berlandaskan pada filsafat positivisme, digunakan untuk meneliti pada populasi atau sampel tertentu. Teknik pengambilan sampel purposive sampling dimana peneliti menentukan pengambilan sampel 
dengan cara menetapkan ciri-ciri khusus yang sesuai dengan tujuan penelitian. Sampel pada penelitian ini terdapat 84 sampel.

Review yang dilakukan oleh Anthoine, dkk (2014) pada sebuah instrumen di bidang kesehatan menyebutkan bahwa Validitas isi, validitas konstruk, validitas kriteria dan konsistensi internal yang paling umum digunakan dalam studi validasi. Dari 114 artikel yang direview, sekitar 92\% dari artikel melaporkan rasio sampel dan jumlah variabel lebih besar dari atau sama dengan 2, sedangkan $25 \%$ memiliki rasio lebih besar dari atau sama dengan 20 . Sekitar 90\% dari artikel memiliki ukuran sampel yang lebih besar dari atau sama dengan 100, sedangkan $7 \%$ memiliki ukuran sampel yang lebih besar dari atau sama dengan 1000.

Menurut Sapnas dan Zeller (2002) berpendapat bahwa ukuran sampel 50 cukup memadai untuk mengevaluasi sifat psikometrik pada ukuran konstruk.
Pernyataan atau item penilaian terdiri dari 2 kategori dengan jumlah 10 Item penilaian. Pengukuran tampak belakang atau sejajar dengan tulang belakang dan dari diukur dari lateral / samping. Menurut Jhonson (2012) dalam artikel Postural Assessment Hands on guides for therapists posisi untuk penilaian posture akan lebih jelas ketika pasien atau klien dengan posisi berdiri.

Pengukuran dengan melihat kondisi neck, shoulder, thoraks, lumbal dan pelvic. 10 item penilaian, 5 dari sejajar dengan tulang belakang (neck, shoulder, thoraks, lumbal dan pelvic) dan 5 item dari samping neck, shoulder, thoraks, lumbal dan pelvic).

Setelah data didapat data diuji dengan Pearson dan cronbach's aplha untuk mengetahui tingkat validitas dan reliabilitas. Alat ukur SG Posture Evaluation tertera pada gambar 1 dibawah ini

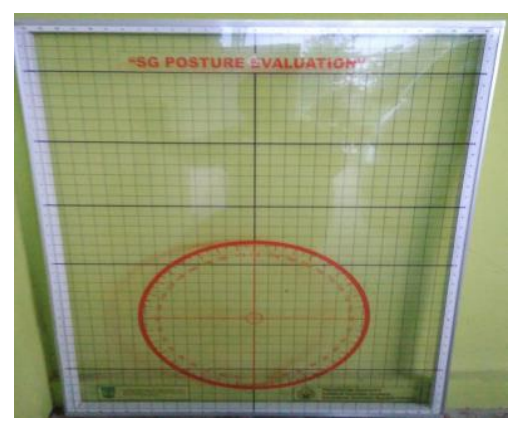

Gambar 1. Alat SG Posture Evaluation

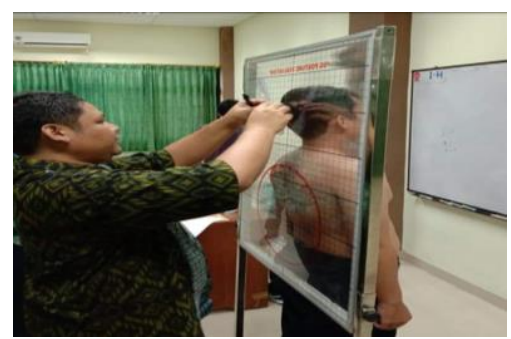

Gambar 2. Menggunakan alat SG Posture Evaluation 


\section{HASIL PENELITIAN}

Hasil yang didapat dari item penilaian postur tulang belakang dari 84 responden, hasil pengukuran dilihat dari
Tulang belakang sisi posterior (balakang) dan dari sisi lateral (samping) didapat dilihat pada tabel 1 :

Tabel 1. Hasil uji Validitas

\begin{tabular}{ccc}
\hline \multicolumn{2}{l}{ Pengukuran dari Posterior / belakang } & \\
\hline \multicolumn{1}{l}{ Item } & Skor & Keterangan \\
\hline (Neck & 170 & Tidak valid \\
Shoulder & $323^{*}$ & Valid \\
Thoraks & 128 & Tidak valid \\
Lumbal & $\mathrm{a} / 0$ & Tidak valid \\
Pelvic & $260^{*}$ & Valid \\
\hline Pengukuran dari lateral/ samping & \\
\hline Item & Skor & Keterangan \\
\hline Neck & $747^{*}$ & Valid \\
Shoulder & $276^{*}$ & Valid \\
Thoraks & $301^{* *}$ & Valid \\
Lumbal & $489^{*}$ & Valid \\
Pelvic & $334^{* *}$ & Valid
\end{tabular}

Hasil uji validitas dapat dilihat digambar 1

dibawah ini:

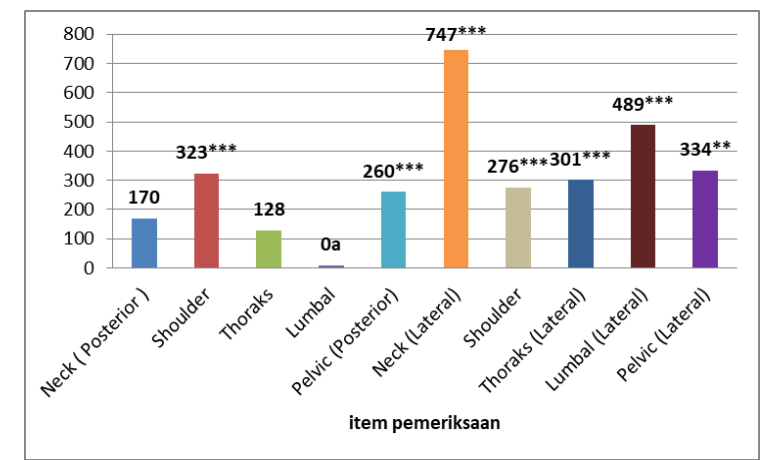

Gambar 3. Hasil Uji Validitas

Tingkat reliabilitas SG Posture evaluation ditandai dengan nilai cronback alpha sebesar 612 nilai ini lebih besar dari 0,6 . sehingga tingkat reliabilitas sangat baik. Menurut Urbina S, (2004) pengujian reliabilitas dapat dihitung dengan menggunakan formula cronbach's alpha.

\section{PEMBAHASAN}

Instrumen penelitian menjadi penentu kualitas data sebuah penelitian. Dalam uji validitas dan reliabilitas alat ukur SG Posture Evaluation dari hasil yang didapat terdapat tingkat validitas pada alat SG Posture Evaluation, 4 item penilaian yang didapat dari hasil 
pengukuran sejajar dengan tulang belakang (neck, shoulder, thoraks, dan pelvic) dan 4 item dari samping neck, shoulder, thoraks, dan pelvic) sedangkan pada item penilaian di lumbal tidak valid karena tidak terdapat nilai dan pada uji reliabilitas alat ukur SG Posture Evaluation didapat tingkat reliabilitas.

Hasil uji korelasi dengan output correlations Statistical Product and Service Solutions (SPSS) menggambarkan tingkat validitas item. Menurut Ghozali (2005) output correlations bisa dilihat hasil dengan tanda bintang adalah valid. Bintang 1 menunjukkan bahwa instrument valid pada 1 kali pengujian dengan taraf signifikansi $95 \% \quad(0,05)$. Bintang 2 menunjukkan bahwa instrument valid pada 2 kali pengujian dengan taraf signifikansi $99 \%(0,01)$ Terdapat korelasi signifikan pada tingkat 0,05 .

SG Posture evaluation reliable ditandai dengan nilai cronback alpha sebesar 612 nilai ini lebih besar dari 0,6. Suatu kontruk atau variabel dikatakan reliable jika memberi nilai cronbachs alpha $>0,60$. nilai alpha yang digunakan sebagai indicator secara umum menggunakan batas 0,60 (Ghozali,2007).

Tingkat validitas dan reliabilitas pada alat ukur sangatlah penting, pada dasarnya, terdapat dua kategori instrumen yang digunakan dalam penelitian, yakni: (1) instrumen yang digunakan untuk memperoleh informasi atau data tentang keadaan obyek atau proses yang diteliti dan (2) instrumen yang digunakan untuk mengontrol obyek atau proses yang diteliti (Santoso 2005).

Validasi postur atau penilaian postur, mengacu pada penerapan seperangkat alat ukur, dari data penilaian postur digunakan untuk memberikan penilaian. Saat menilai postur, posisi tubuh secara keseluruhan diperiksa, struktur tulang dinilai adakah kelainan dan kerusakan. Kondisi sendi diperiksa dengan posisi netral, perubahan sudut dan rentang gerak. Otot diperiksa dengan diperiksa apakah ada jumlah yang sama di sisi kiri dan kanan tubuh. Melakukan penilaian postural memberi hasil lebih banyak informasi (Purva C. Badhe and Vaishali Kulkarni 2018) .

Uji validitas instrumen dilakukan untuk menunjukan keabsahan dari instrumen yang akan dipakai pada penelitian. Menurut Arikunto (2006) "Validitas adalah suatu ukuran yang menunjukkan tingkat kevalidan dan kesahihan suatu instrumen". Pengertian validitas tersebut menunjukan ketepatan dan kesesuaian alat ukur yang digunakan untuk mengukur variabel. Alat ukur dapat dikatakan valid jika benar-benar sesuai dan menjawab secara cermat tentang variabel yang akan diukur. Validitas juga menunjukkan sejauh mana ketepatan pernyataan dengan apa yang dinyatakan sesuai dengan koefisien validitas

Dari hasil dan pembahasan tingkat validitas dan reliabilitas alat ukur SG Posture Evaluation didapat dengan mengukur keadaan posture klien atau responden dari 5 titik yaitu bagian neck, shoulder, thoraks, lumbal dan pelvic. pengukuran sejajar dengan tulang belakang dan dari sisi samping.

\section{KESIMPULAN}

Terdapat tingkat validitas dan reliabilitas alat ukur $S G$ Posture Evaluation. Alat ukur $S G$ Posture Evaluation dapat digunakan untuk alat pengukuran sejajar dengan tulang belakang dan dari sisi samping. 


\section{DAFTAR RUJUKAN}

Anthoine, E., Moret, L., Regnault, A., Sabille, V \& Jean-Benoit Hardouin (2014). Sample size used to validate a scale: a review of publications on newly-developed patient reported outcomes measures. Health and Quality of Life Outcomes

Azwar, S. (2005). Dasar-Dasar Psikometri.Yogyakarta: Pustaka Pelajar.

Bhisma, M. (2011). Validitas Dan Reliabilitas Pengukuran. Matrikulasi Program Studi Doktoral,

Cherry Kendra. (2012). What Is Reliability?, dikutip dari http://psychology.about.com/od/rese arc hmethods/f/reliabilitydef.htm. diakses tanggal 18-9-2019

Coaley , K. (2010). An Introduction to Psychological Assessment and Psychmetrics. London: Sage.

Coaley, K. (2010). An Introduction to Psychological Assessment and Psychmetrics.London: Sage.

Devellis, R. F. (2003). Scale Development. London: Sage Publications Fakultas Kedokteran, UNS.

fk.uns.ac.id/index.php/download/file 161

Ghozali, Imam. (2007). Aplikasi Analisis Multivariate Dengan Program SPSS, Universitas Diponogoro, Semarang.

Ghozali, Imam. (2005). Aplikasi Analisis Multivariate dengan Program SPSS
Semarang: BP Universitas

Diponegoro.

Jane Jhonson. (2012). Postural Assessment Hands on guides for therapists. Human Kinetics Publication

Notoatmodjo. (2005). Metodologi Penelitian Kesehatan, Jakarta: Rineka Cipta

Purva C. Badhe and Vaishali Kulkarni. (2018). A Review on Posture Assessment . IOSR Journal of Sports and Physical Education (IOSR-JSPE) Volume 5, Issue 5

Santoso, Gempur. (2005). Metodologi Penelitian Kuantitatif dan Kualitatif. Prestasi Pustaka: Surabaya

Sapnas, K. G., \& Zeller, R. A. (2002). Minimizing sample size when using exploratory factor analysis for measurement. Journal of Nursing Measurement, 12(2), 97-109

Sari, S., Tirtayasa, K., \& Sugijanto. (2013). Swiss Ball Exercise Dan Koreksi Postur Tidak Terbukti Lebih Baik Dalam Memperkecil Derajat Skoliosis Idiophatik Daripada Klapp Exercise Dan Koreksi Postur Pada Anak Usia 11-13 tahun. Sport and Fitness Journal 1(2).

Sugiyono. (2005). Statistika Untuk Penelitian, Bandung: Alfabeta

Sugiyono. (2016). Metode Penelitian Kuantitatif, Kualitatif dan R\&D. Bandung: PT Alfabet 
Suryabrata, S. (2005). Pengembangan Alat Ukur Psikologis.Yogyakarta: Penerbit Andi

Urbina S. (2004), Essentials of physhological Testing, New Jersey: John Wiley \& Son

Zulkifli M. (2009). Validitas dan Reliabilitas Suatu Instrumen Penelitian. Jurnal Tabularasa PPS UNIMED Vol.6 No. 1 